\title{
Erratum to: A Comparative Analysis of a Community and General Sample of Lesbian, Gay, and Bisexual Individuals
}

\author{
Lisette Kuyper $\cdot$ Henk Fernee $\cdot$ Saskia Keuzenkamp
}

Published online: 14 February 2015

(c) Springer Science+Business Media New York 2015

\section{Erratum to: Arch Sex Behav \\ DOI 10.1007/s10508-014-0457-1}

We have discovered that the OR and the Wald statistic in Table 5 for men and suicidal plans are mistakenly the values of the model constant and not the values belonging to the relevant variable. The correct values are: $\mathrm{Wald}=1.56 ; \mathrm{OR}=.81, p=.21$. This also leads to an incorrect line in the section "Mental Health." The sentence that requires correction is: "Panel men, compared to community men, reported lower levels of psychological distress, lower levels of suicidal thoughts, and lower levels of actual plans for suicide." It should read: "Panel men, compared to community men, reported lower levels of psychological distress and lower levels of suicidal thoughts." We apologize to the readers for any inconvenience caused by our mistake. The correct version of Table 5 is a given below.

Table 5 Differences in mental health characteristics between community and panel sample

\begin{tabular}{|c|c|c|c|c|}
\hline & \multicolumn{2}{|l|}{ Men } & \multicolumn{2}{|c|}{ Women } \\
\hline & OR & Wald & OR & Wald \\
\hline Psychological distress & .73 & $25.13 * * *$ & .81 & $8.39 * *$ \\
\hline \multicolumn{5}{|l|}{ Suicidality } \\
\hline Suicidal thoughts & .74 & $23.26 * * *$ & .92 & 1.84 \\
\hline \multicolumn{5}{|l|}{ Suicidal plans ${ }^{\mathrm{a}}$} \\
\hline No & Ref & Ref & Ref & Ref \\
\hline Yes & .81 & 1.56 & 1.02 & .01 \\
\hline
\end{tabular}

The dependent variable was type of sample $(0=$ community sample; $1=$ panel sample $)$. All analyses were controlled for social demographics (age, education, employment, religiousness, ethnicity, and urbanicity). Separate analyses were conducted for psychological distress $\left(N_{\text {men }}=2,142 ; N_{\text {women }}=\right.$ $2,210)$, suicidality thoughts $\left(N_{\text {men }}=2,138 ; N_{\text {women }}=2,198\right)$, and suicidality plans $\left(n_{\text {men }}=1,041 ; n_{\text {women }}=1,150\right)$

$* * p<.01 ; * * * p<.001$

${ }^{a}$ Item was only completed by participants indicating they have had suicidal thoughts

The online version of the original article can be found under doi:10.1007/ s10508-014-0457-1.

\section{Kuyper $(\bowtie) \cdot$ H. Fernee}

Department of Education, Minorities, and Methodology, The

Netherlands Institute for Social Research, POB 16164, 2500 BD

The Hague, The Netherlands

e-mail:1.kuyper@scp.nl

S. Keuzenkamp

Movisie, Utrecht, The Netherlands 